\title{
Performance and Energy Requirements of Gestating Grasscutters Fed Agro-Industrial By-Products
}

\author{
G. S. I. Wogar (Corresponding author) \\ Department of Animal Science, University of Calabar, PMB 1115, Calabar, Nigeria \\ Tel: 234-803-718-4125_E-mail: ikaniw@yahoo.com \\ L. N. Agwunobi \\ Department of Animal Science, University of Calabar, PMB 1115, Calabar, Nigeria \\ Tel: 234-803-580-4162 E-mail: link_leonard@yahoo.com
}

Received: August 31, 2011

doi:10.5539/jas.v4n3p275

\author{
Accepted: September 15, 2011
}

URL: http://dx.doi.org/10.5539/jas.v4n3p275

\begin{abstract}
The grasscutter (Thryonomys swinderianus) is a large herbivorous rodent of the grasslands of Sub-Sahara Africa. It is an important source of much-needed animal protein; and holds promise as an acceptable 'bushmeat' substitute for the hunted and endangered wildlife animal species of West Africa. The intensive production of the grasscutter would require the supply of inexpensive and adequate dietary nutrients. Energy requirement was determined using sixteen 8-months old gestating grasscutters. The grasscutters were separated into four groups and fed diets, which differed in their energy contents of 2000, 2200, 2400, and 2600 kilocalories metabolizable energy per kilogram (Kcal ME/kg). The test diets had the same crude protein (CP) level of $18 \%$. The results showed that total feed intake was significantly $(\mathrm{P}<0.05)$ higher on the $2200 \mathrm{kcal} \mathrm{ME} / \mathrm{kg}$ diet than on other diets. Weight gain was highest on the $2200 \mathrm{kcalME} / \mathrm{kg}$ diet. Average litter size was significantly $(\mathrm{P}<0.05)$ higher on the $2200 \mathrm{kcalME} / \mathrm{kg}$ and $2400 \mathrm{kcal} \mathrm{ME} / \mathrm{kg}$ diets. The average birth weight of grasscutter pups was significantly $(\mathrm{P}<0.05)$ higher on the $2200 \mathrm{kcalME} / \mathrm{kg}$ and $2600 \mathrm{kcalME} / \mathrm{kg}$ diets. Taken together, growth and reproductive performance of gestating grasscutters was superior, on the $2200 \mathrm{kcalME} / \mathrm{kg}$ diet, to performance on other diets. The results of this study suggest that agro-industrial by-products, soybean and wheat offal in cassava-based diets, can effectively be used at dietary energy level of $2200 \mathrm{kcalME} / \mathrm{kg}$, to rear gestating grasscutters. It is, therefore, concluded that the optimum dietary energy requirement of gestating grasscutters is $2200 \mathrm{kcal} \mathrm{ME} / \mathrm{kg}$.
\end{abstract}

Keywords: Gestating grasscutters, Optimum energy requirement, Low-cost, Agro-industrial by-products

\section{Introduction}

African countries have the lowest animal protein intake in the world. It is reported that populations in African countries consume the least amount of meat (Andrew, 2003). The per capita per year consumption of meat in Sub-Sahara Africa is estimated at $13.4 \mathrm{~kg}$, and projected to be $33.8 \mathrm{~kg}$ in 2030 (Bruinsma, 2003). The production of animal protein is insufficient to meet the demands of the ever-increasing population. The supply of adequate animal protein through poultry production has not been satisfactory in these parts of the world because of the high mortality rate, and the high cost of feed and day old chicks (Agwunobi and Ekpenyong, 1990).

There is, therefore, the need to diversify animal protein production. Grasscutters are herbivores which, in captivity, could be fed green or dry forages (Van Zyl and Delport, 2010) which are accompanied with concentrates. The fermentation of fibre in the gut of herbivores results in the production of volatile fatty acids (VFAs) (Michalet-Doreau, 2002) which are absorbed across the epithelial membrane. VFAs account for much of the metabolizable energy supply to the animal (Kristensen 2005).

It has been reported (Karikari and Nyameasem, 2009) that increase in the dietary components of crude fibre (CF), acid detergent fibre (ADF) and neutral detergent fibre (ADF) decreased digestibility and daily weight gain in grasscutters. In another study with grasscutters, van Zyl et al. (1999) found that high dietary fibre reduced the digestibility of dry matter (DM), protein and fat, while the digestibility of fibre components (NDF, ADF, hemicellulose and cellulose) was comparable to that of grasscutters on the low fibre diet.

Changes in energy requirements of the animal depend on the feed type (Annor et al., 2008) and on the physiological and productive status of the animal (Keunen et al., 2002). These factors cause feed intake to change according to the nutrient requirements of the animals (Baumgardt, 1970). Growing grasscutters have been reported to have higher weight gains, though not statistically significant, on dietary energy of 2800 $\mathrm{kcalME} / \mathrm{kg}$ than on lower dietary energy levels (Adeniji, 2008). 
Unlike the production of conventional livestock such as poultry and pigs, intensive production of the grasscutter does not require expensive feed concentrates. The availability and use of low-cost feeds in the production of grasscutters is particularly important since the conventional livestock feeds have become too expensive for the traditional farmer (Ojewole et al., 2005). The use of supplements along with the feeding of roughages has been found to improve performance in animals (Agboola, 2000). However, the use of soybean, groundnut cake and blood meal as supplements in diets was found to have no significant effect on performance of growing grasscutters (Adeniji, 2009).

Soybean is the most widely used protein supplement in the diet of ruminants. It is the standard for the comparison of other protein sources (Newkirk, 2010), and has one of the highest (47.6\%) levels of essential amino acids among the common plant protein supplements used in animal feeds (Schwab, 1999). The proximate composition of soybean meal, including the acid detergent fibre (ADF) and the neutral detergent fibre (NDF), depends on the processing method (Sauvant et al., 2004). Wheat offals are widely used as a source of energy and fibre in the diets of animals. On dry matter basis, the chemical composition of wheat offals is $87.6 \% \mathrm{DM}, 16.9 \%$ CP, $11.3 \%$ CF, 6.4\% ash, 3.8\% ether extract, and 61.6\% nitrogen free extract (Malau-Aduli et al., 2003).

Little is known about the nutrient requirements of the grasscutter in its various physiological and productive states.

There is need to investigate the effectiveness of easily available and low-cost feedstuffs in the improvement of performance of the grasscutter in its various productive states. The objective of this study, therefore, is to determine the reproductive performance and dietary energy requirements of gestating grasscutter fed cassava and agro-industrial by-products, namely soybean and wheat offal.

\section{Materials and methods}

The study was carried out at the Grassccutter Research Farm at Calabar, under the supervision of the Department of Animal Science, University of Calabar, Calabar, Nigeria. Calabar is at latitude $3^{0}$ North and longitude $7^{0}$ East. It has an annual rainfall of 2650 to $3000 \mathrm{~mm}$ and relative humidity of 57 to $93 \%$. The annual temperatures are between 25 and $32^{\circ} \mathrm{C}$ (Calabar Travel Guide, 2010). The study, which lasted for twenty (20) weeks, was conducted between the months of February and July, 2009.

\subsection{Experimental diets}

Four different dietary energy levels of $2000 \mathrm{kcalME} / \mathrm{kg}$ (ED1), $2200 \mathrm{kcalME} / \mathrm{kg}$ (ED2), $2400 \mathrm{kcalME} / \mathrm{kg}$ (ED3), and $2600 \mathrm{kcalME} / \mathrm{kg}$ (ED4) were formulated, with wheat offal and soybean as the experimental agro-industrial by-products. The energy content of each diet was estimated from the known energy density of each ingredient of the diet. Cassava was used as a binding agent in the diet and as an additional source of energy (Table 1). The crude protein (CP) levels of the diets were equalized to $18 \% \mathrm{CP}$. All the ingredients used were purchased from the local market in Calabar. A thick paste of the ingredients was made using cassava starch as the binding agent. The paste was pelleted in a pelleting machine and dried in a kerosene-fired oven at $75^{\circ} \mathrm{C}$. The composition of the test diets is shown in Table 1, while the proximate composition of the diets is shown in Table 2.

\subsection{Research animals}

Sixteen (16) grasscutters, which had been confirmed pregnant were used in the study. The pregnant grasscutters were 8 months old and weighed between 2.30 and $2.38 \mathrm{~kg}$.

\subsection{Management of research animals}

The grasscutters were individually housed in clearly and properly-labelled concrete cells measuring $150 \times 75 \times$ $35 \mathrm{~cm}$ (length $\mathrm{x}$ width $\mathrm{x}$ height). The housing provided for only one opening ( $35 \mathrm{high} \mathrm{x} 45 \mathrm{~cm}$ wide) into the cell in order to eliminate cross-ventilation and prevent the adverse effect of cold on grasscutters, which are very susceptible to pneumonia. Temperatures in the cells were in the range of $25-31^{0} \mathrm{C}$ during the experimental period.

The grasscutters were randomly allotted, in groups of four, to the four treatment diets. Each group was randomly fed one of the four dietary energy levels. There were four replicates per treatment, with one (1) grasscutter per replicate.

Growing grasscutters, used in the study were reared on a grower's concentrate along with elephant grass (Pennisetum purpureum) until they were diagnosed as pregnant. The pregnant grasscutters were thereafter transferred to the experimental diet, which was served along with elephant grass. On introduction into the cells, the animals were dewormed and provided with anti stress agents in drinking water. Elephant grass (Pennisetum purpureum), which was cut and allowed to wilt for two days, was weighed and fed daily as basal diet. Water, diet and elephant grass were supplied ad libitum.

The animals were weighed, at the beginning and every two weeks thereafter, during the 20 weeks of the study. All cells were cleaned daily in order to ensure an acceptable level of sanitation. 


\subsection{Data collection and statistical analysis}

Data collection on the various parameters of interest was started after seven days of introducing gestating grasscutters to the experimental diet. Records were kept of the following observations: daily forage intake (g); daily forage dry matter intake $(\mathrm{g})$, which was estimated as $12 \%$ Dry Matter content of elephant grass; daily diet intake (g); daily total feed intake (g), which was the total intake of forage dry matter and diet; daily weight gain of does (g); weight of does at end (terminal weight) of gestation (g); average number of pups ( No/litter size) kindled; average birth weight (g) of pups and cost of diet (N.K).

The gestating grasscutters were obtained from five does, which had kindled within a 24-hour period. The differences between the weights of grasscutters used in the study were within a close range. Grasscutters were randomly allocated to the four test diets, therefore, from a pool without consideration to weight differences. The design of the experiment was the Completely Randomized Design. All the data collected during the period of the experiment were subjected to analysis of variance, using the Genstat (2007) software. Significant means were separated by Duncan's Multiple Range test (Steel and Torrie, 1980).

\section{Results and Discussion}

The proximate composition of the experimental diets is presented in Table 2. The results show that while there were no differences between diets in respect of their percentage composition of dry matter and crude protein, there were significant differences in respect of their composition of crude fibre, ether extract, ash and nitrogen free extract.

The effects of feeding different energy levels, on gestating grasscutters, are presented in Table 3.

\subsection{Growth Performance}

\subsubsection{Feed intake}

The results show that gestating grasscutters fed the low dietary energy consumed more feed than those fed the high dietary energy. Forage intake, diet intake and total feed intake increased significantly $(\mathrm{P}<0.05)$ with increase in dietary energy up to 2200 kilocalories (kcal) metabolizable energy (ME) per kilogram ( $\mathrm{kg}$ ) and decreased thereafter. This agrees with the findings of Meredith (2010) that rabbits eat to satisfy their energy requirement. The findings of this study suggest that gestating grasscutters adjust dietary energy intake to meet requirements for gestation. Gestating grasscutters, therefore, adjust their feed intake according to the concentration of energy in their feed in order to satisfy demand. Similar findings have been reported in respect of feed intake and nutrient requirements of rabbits (Lebas et al., 1986). The average daily total feed intake (143.52 to $166.12 \mathrm{~g}$ ) obtained under the conditions of this experiment is within the range (150 to $250 \mathrm{~g}$ ) reported by Mensah (1995).

\subsubsection{Daily weight gain}

The significantly $(\mathrm{P}<0.05)$ high amount of feed consumed by gestating grasscutters on the $2200 \mathrm{kcalME} / \mathrm{kg}$ diet could explain the higher weight gain on that diet. The high feed intake on the lower dietary energy diets could be due to the significantly higher levels of crude fibre in those diets. The findings also suggest higher digestibility of the dietary crude fibre fractions (ADF and NDF) on the $2200 \mathrm{kcalME} / \mathrm{kg}$ test diet than on other diets. This agrees with the findings of Karikari and Nyameasem (2009) that daily weight gain among grasscutters decreased with increase in dietary levels of CF, ADF and NDF. However, van Zyl (1999) reported that the digestibility of $\mathrm{ADF}, \mathrm{NDF}$, hemicellulose and cellulose among grasscutters fed a high fibre diet was comparable to digestibility of these fractions among grasscutters on a low fibre diet. High fibre diets have been reported to increase feed intake in rabbits (Jokthan et al., 2006). High fibre diets are also associated with decreased caloric density. Hence, the need for increased feed intake to meet the energy demand of gestating grasscutters on the lower energy diets. The higher weight gain on the lower energy diets, which is due to higher feed intake, agrees with the report of NRC (1977) that rabbits voluntarily adjust their feed intake to satisfy energy demand. The reduced weight gain on the higher dietary energy diets could be due to the significantly lower fibre levels in those diets (Taiwo et al., 2005). Low fibre diets have been reported to have prolonged retention times in the caecum resulting in reduced feed intake and weight gain (Bawa et al., 2008).

Though not statistically significant, average daily weight gain of gestating grasscutters increased with increase in dietary energy level, with the highest weight gain (17.41g) recorded for those fed the $2200 \mathrm{kcal} \mathrm{ME} / \mathrm{kg}$ diet. Similarly, feed conversion ratio and cost to gain improved with increase in dietary energy level. The best feed conversion ratio (9.51) and cost to gain ratio (0.44) were obtained on the $2200 \mathrm{kcal} \mathrm{ME} / \mathrm{kg}$ diet. This implies that feed utilization in gestating grasscutters was more efficient and more cost effective on the $2200 \mathrm{kcalME} / \mathrm{kg}$ diet. The average daily weight gain (10.91- 17.41g) obtained under the conditions of this study was higher than weight gain (8 to 13g) reported by Jori and Chardonnet (2001). These results could explain the higher (4205.21g) terminal weight (weight at end of gestation) on the $2200 \mathrm{kcalME} / \mathrm{kg}$ diet than on other diets. The higher terminal 
weight was indicative of superior maternal well-being of gestating grasscutters on the $2200 \mathrm{kcalME} / \mathrm{kg}$ diet than on other diets. These findings suggest that maternal adjustments (Smith and Somade, 1994) to meet the energy and nutrient requirements of gestating grasscutters was superior on the $2200 \mathrm{kcalME} / \mathrm{kg}$ to adjustments on other diets.

\subsection{Reproductive performance}

\subsubsection{Litter size and birth weight of pups}

It was observed that the litter size increased significantly $(\mathrm{P}<0.05)$ with increase in dietary energy levels. The results indicate that higher litter sizes were obtained when dietary energy levels were in the range of 2200 to $2400 \mathrm{kcalME} / \mathrm{kg}$. The highest ( 8 pups) litter size was obtained when gestating grasscutters were fed the 2400 $\mathrm{kcal} \mathrm{ME} / \mathrm{kg}$ diet, while the smallest (3 pups) litter size was obtained on the $2600 \mathrm{kcalME} / \mathrm{kg}$ diet.

The litter size range of 3 to 8 pups per litter obtained in this study compares favourably with litter sizes in the range of 2.67 to 5 pups per litter reported by other studies (Lameed and Ogundijo, 2006; Ogunjobi, 2008 and Henry, 2011).

The birth weights of pups obtained in this study ranged from $117.21 \mathrm{~g}$ on the $2400 \mathrm{kcalME} / \mathrm{kg}$ diet to $182.22 \mathrm{~g}$ on the $2600 \mathrm{kcalME} / \mathrm{kg}$ diet. These findings indicate that the birth weights of pups were significantly $(\mathrm{P}<0.05)$ higher among gestating grasscutters on the $2600 \mathrm{kcalME} / \mathrm{kg}$ diet, which also had the smallest litter size. Birth weights of pups were significantly $(\mathrm{P}<0.05)$ lower among gestating grasscutters on the $2400 \mathrm{kcalME} / \mathrm{kg}$ diet, which also had the largest litter size. Average birth weights obtained in this study were within ranges reported by other studies (Addo, 2002 and Henry, 2011). This finding suggests that the birth weight of pups decreased with increase in litter size. This inverse relationship between birth weight and litter size has been reported by other studies (Odubote and Akinokun, 1991; Henry, 2011).

\subsection{Cost to gain ratio}

The daily cost of feeding gestating grasscutters with the test diet significantly $(\mathrm{P}<0.05)$ increased with increase in dietary energy levels. This was expected since dietary energy, next to protein, is among the most costly components of diets. However, though the cost to gain ratio did not differ significantly among gestating grasscutters on the various test diets, the results suggest that the $2200 \mathrm{kcalME} / \mathrm{kg}$ diet was the most cost effective.

\section{Conclusion}

Growth and reproductive performance of gestating grasscutters was superior, on the $2200 \mathrm{kcalME} / \mathrm{kg}$ diet, to performance on other diets. The results of this study suggest that agro-industrial by-products, soybean and wheat offal in cassava-based diets, can most effectively be used at dietary energy level of $2200 \mathrm{kcalME} / \mathrm{kg}$ to rear gestating grasscutters. It is, therefore, concluded that the optimum dietary energy requirement of gestating grasscutters is $2200 \mathrm{kcal} \mathrm{ME} / \mathrm{kg}$.

\section{References}

Adeniji, A. A. (2008). Effect of feeding three protein sources with or without fishmeal supplementation on the performance of growing grasscutters. Asian Journal of Animal and Veterinary Advances, 3 (2): 98-103. http://dx.doi.org/10.3923/ajava.2008.98.103

Adeniji, A. A. (2009). Protein and energy requirements of weaner grasscutters. Journal Animal Nutrition and Feed Techonology, 9 (1): 73-79. [Online] Available: www.cabdirect.org/abstracts/20093123364.html

Addo, P. G. (2002). Detection of mating, pregnancy and imminent parturition in the grasscutter (Thryonomys swinderianus). Livest. Res. Rural Dev., 14: 8-13.

Agboola, P. O. (2000). Grasscutter farming seminar paper presented at Forest and Wildlife Conservation Division, Forest Research Institute, Ibadan, Nigeria.

Agwunobi, L.N. \& Ekpenyong, T. E. (1990). Nutritive and economic value of Guinea fowl (Numida meleagris). Production in Developing Countries. J. Sci. Food Agric., 52:301-308. http://dx.doi.org/10.1002/jsfa.2740520303

Andrew W. S. (2003). Global production and consumption of animal source foods. Animal Production and Health Division, Food and Agricultural Organization of the United Nations. The American Society for Nutritional Sciences J. Nutr., 133: 40485-40535.

Annor, S. Y., Kagya-Agyemang, J. K.., Abbam, J. E. Y. Oppong, S. K. \& Agoe, I. M. (2008). Growth Performance of grasscutter (Thryonomys swinderianus) eating leaf and stem fractions of guinea grass (Panicum maximum). Livestock Research for Rural Development, 20 (8), 2008.

Baumgardt, B.R. (1970). Control of feed intake in the regulation of energy balance. In: Physiology of Digestion and Metabolism in Ruminants. A.T. Phillipson (Ed.). Oriel Press Ltd., Newcastle. 
Bawa, G. S., Ajide, S. O. Adeyinka, I. A. \& Ajala, M. K. (2008). Effect of varying levels of groundnut haulms and cowpea shells on the performance weaned rabbits. Asian Journal of Animal and Veterinary Advances, 3 (2): 54-61. http://dx.doi.org/10.3923/ajava.2008.54.61

Bruinsma, J. D. (2003). World Agriculture: towards 2015/2030. An FAO perspective. Rome, Food and Agicultural Organization of the United Nations/London, Earthscan, 2003.

FAO. (1970). Provisional Indicative Plan for Agricultural Development. Vols 1 and 2. FAO Rome.
Calabar
Travel
Guide.
(2010).
[Online]
Available:

www.travelpod.co.uk/travel-blog-entries/calabarnigeria/.../tpod.html

Genstat. (2007). Lawes Agricultural Trust. Rothamsted Experimental Station, England. [Online] Available: www.vsn.co.uk/software/genstat/

Henry, A. J. (2011). Reproductive performance of grasscutter does at first parity and growth performance of their F1 generation. Asian Journal of Animal Science, 5 (4): 289-295. http://dx.doi.org/10.3923/ajas.2011.289.295

Jokthan, G. E., Alawa, J. P. Adeyinka I. A. \& Adamu, A. M. (2006). The effect of fibre sources on the performance of young rabbits. Nig. J. Anim. Prod., 33: 192-196.

Jori, F. \& Chardonnet, P. (2001). Cane rat farming in Gabon; status and perspective. Proceedings of the $5^{\text {th }}$ International Wildlife Ranching Symposium, March 2001, Pretoria, South Africa, pp:33-51.

Karikari, P. K., Nyameasem, J. K. (2009). Productive performance and carcass characteristics of captive grasscutters (Thryonomis swinderianus) fed concentrate diets containing varying levels of guinea grass. World Applied Sciences Journal, 6(4)

Keunen, J. E., Plaizier, J. C., Kyriazakis, L., Duffield, T. F., Widowski, T. M., Lindinger, M. I. \& Mcbride, B. W. (2002). Effect of subacute ruminal acidosis model on the diet selection of dairy cows. Journal of Dairy Science, 85 (12): 3304-3313. http://dx.doi.org/10.3168/jds.s0022-0302(02)74419-6

Kristensen, N.B. (2005). Splanchnic metabolism of volatile fatty acids in the dairy cow. Animal Science, 80: 2-9. http://dx.doi.org/10.1079/ASC41250003

Lameed, G.A. \& Ogundijo, O. O. (2006). Effect of varied dietary protein levels on the reproductive performance of grasscutters (Thryonomys swinderianus) in captivity. Journal of Animal and veterinary advances, 5(5): 361 363. [Online] Available: www.medwelljournals.com/abstract/?doi=javaa.2006.361.363

Lebas, F., Coudert, P., Rouvier, R. \& Rochambeau, H. D. (1986). The Rabbit Husbandry Health and Production. FAO, Rome, Italy, pp: 45-107. [Online] Available: www.fao.org/docrep/X5082E/X5082E00.htm

Malau-Aduli, B. S., Eduvie, L. O., Lakpini, C. A. M. \& Malau-Aduli, A. E. O. (2003). Variations in liveweight gain, milk yield and composition of Red Sokoto goats fed crop-residue-based supplements in subhumid zone of Nigeria. Livestock Production Science, 83(2003): 63-71. [Online] Available: www.scientificcommons.org $/ 53482086$

Mensah, G.A. (1995). Feed intake and digestibility in grasscutters (Thryonomys swinderianus). Tropicultura, 13: 123-124.

Meredith, A. (2010). The importance of diet in rabbit. Anna Meredith (ED.), Head of Exotic Animal Service Royal (Dick) School of Veterinary Studies University of Edinburgh. The British Rabbit Council. Purefoy house, 7 Kirkgate, Newak, Notts NG24 1AD. [Online] Available: www.thebrc.org/diet.htm

Michalet-Doreau, B. (2002). A comparison of enzymatic and molecular approaches to characterize the cellulolytic microbial ecosystems of the rumen and the caecum. J. Anim. Sci., 80: 790-796. [Online] Available: http://jas.fass.org/content/77/2/416.full.pdf

NRC (National Research Council). (1977). Nutrient requirement of poultry. $8^{\text {th }}$ Rev. Edn., National Academy of Science, USA Edn., WH Freedom and Co., San Francisco, Washington DC.

Odubote, I. K. \& Akinokun, J. O. (1991). Evaluation of reproductive and body weight performances of the New Zealand white rabbits in the humid tropics of Nigeria. Nig. J. Anim. Prod., 18: 61-65.

Ogunjobi, J. A. (2008). Reproductive performance of cane rat (Thryonomys swinderianus Temminck 1827) breeding stocks and litter rate of survival reared using two common housing materials. Proceedings of the 33rd Annual Conference of the Nigerian Society for Animal Production, March 17-20, Nigeria, pp. 208-209.

Ojewole, G. S., Okoye, F. C. \& Ukoha, O. A. (2005). Comparative utilization of three animal protein sources by broiler chickens. Int. J. Poult. Sci., 4: 462-467. http://dx.doi.org/10.3923/ijps.2005.462.467

Newkirk, R. (2010). Soybean in ruminant diets. In: Soybean Industry Guide. $1^{\text {st }}$ Edition. pp. 26-27. 
Schwab, C. G. (1995). Protected proteins and amino acids for ruminants. In: Biotechnology in Animal Feeds and Animal Feeding, Pp.115.VCH, NY. http://dx.doi.org/10.1002/9783527615353.ch7

Smith, O.B. \& Somade, B. (1994). Interactions between nutrition and reproduction in farm animals. Proceedings of a Regional Seminar held by the Animal Production International Found. (RSAPIF'94), Science, IFS, Niamey, Niger, pp: 7-26.

Steel, R. G. D. \& Torrie. J. H. (1980). Principles and Procedures of Statistics - A Biometrical Approach, $2^{\text {nd }}$ edn, McGraw Hill Book Co., New York.

Taiwo, A. A., Adejuyigbe. A. D., Adebowale, E. A. Oshotan, J. S. \& David, O. O. (2005). Performance and nutrient digestibility of weaned rabbits fed forages supplemented with concentrate. Nig. J. Anim. Prod., 32: 74-78.

Van Zyl, A., Meyer, A. J. and van der Merwe, M. (1999). The influence of fibre in the diet on growth rates and digestibility of nutrients in greater cane rat (Thryonomis swinderianus). Comparative Biochemistry and

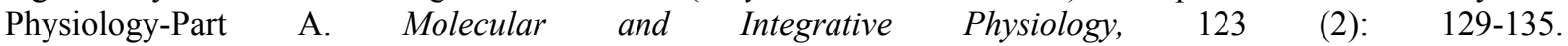
http://dx.doi.org/10.1016/s1095-6433(99)00034-3

Van Zeal, A. and Delport. J. A. (2010). Digestibility of nutrients and aspects of the digestive physiology of the Greater Cane Rat (Thryonomys swinderianus) in two seasons. African Zoology, 45 (2): 254-264. http://dx.doi.org/10.3377/004.045.0204

Table 1. Composition of Experimental Diets for Determination of Energy Requirements of Lactating Grasscutters

\begin{tabular}{|l|l|l|l|l|}
\hline Ingredients & \multicolumn{4}{|l|}{ Experimental diets (ED) (kcalME/kg) } \\
\hline & 2000 & 2200 & 2400 & 2600 \\
\hline Cassava & 16.10 & 29.60 & 43.00 & 56.50 \\
\hline Wheat offal & 66.70 & 46.70 & 27.00 & 7.00 \\
\hline Soybean meal & 13.20 & 19.70 & 26.00 & 32.50 \\
\hline Vitamin premix & 0.50 & 0.50 & 0.50 & 0.50 \\
\hline Bone meal & 3.00 & 3.00 & 3.00 & 3.00 \\
Salt & 0.50 & 0.50 & 0.50 & 0.50 \\
\hline Total & 100.00 & 100.00 & 100.00 & 100.00 \\
\hline
\end{tabular}

Table 2. Proximate Composition of Experimental Diets for Determination of Energy Requirements of Lactating Grasscutters

\begin{tabular}{|l|l|l|l|l|}
\hline Nutrients (\% DM) & \multicolumn{4}{|c|}{ Experimental Diets (ED) (kcalME/kg) } \\
\hline & 2000 & 2200 & 2400 & 2600 \\
\hline Dry matter & 5.58 & 86.46 & 86.37 & 86.44 \\
Crude protein & 18.15 & 18.35 & 18.60 & 18.75 \\
\hline Crude fibre & 21.45 & 13.86 & 7.80 & 4.35 \\
\hline Ether extract & 4.24 & 2.42 & 1.20 & 0.25 \\
\hline Ash & 12.54 & 12.58 & 10.52 & 7.39 \\
\hline Nitrogen Free Extract & 29.20 & 39.25 & 48.25 & 54.95 \\
\hline Calculated ME (kcal/kg) & 2025.46 & 2205.34 & 2434.35 & 2694.28 \\
\hline
\end{tabular}

Table 3. Effect of varying dietary energy levels on gestating grasscutters

\begin{tabular}{|l|l|l|l|l|l|}
\hline \multirow{2}{*}{ PARAMMETERS } & \multicolumn{5}{|l|}{ EXPERIMENTAL DIETS (ED) (Kcal/ME/kg) } \\
\cline { 2 - 6 } & 2000 & 2200 & 2400 & 2600 & SEM \\
\hline Initial body weights $(\mathrm{g})$ & 2369.11 & 2310.21 & 2378.13 & 2301.22 & 72.40 \\
\hline Terminal weights $(\mathrm{g})$ & 3451.23 & 4205.21 & 3806.11 & 3633.13 & $74.61^{\mathrm{ns}}$ \\
\hline Average daily weight gain $(\mathrm{g})$ & 10.91 & 17.41 & 13.62 & 12.43 & $2.23^{\mathrm{ns}}$ \\
\hline Average daily forage intake $(\mathrm{g})$ & $291.71^{\mathrm{a}}$ & $296.11^{\mathrm{a}}$ & $265.90^{\mathrm{b}}$ & $277.21^{\mathrm{ab}}$ & 7.21 \\
\hline Average daily forage DM intake (g) & $35.23^{\mathrm{a}}$ & $36.32^{\mathrm{a}}$ & $32.10^{\mathrm{b}}$ & $33.31^{\mathrm{b}}$ & 0.81 \\
\hline Average daily diet intake (g) & $128.11^{\mathrm{a}}$ & $129.40^{\mathrm{a}}$ & $98.61^{\mathrm{b}}$ & $110.22^{\mathrm{ab}}$ & 7.92 \\
\hline Average daily total feed intake (g) & $166.12^{\mathrm{a}}$ & $164.42^{\mathrm{a}}$ & $130.51^{\mathrm{b}}$ & $143.52^{\mathrm{ab}}$ & 8.31 \\
\hline Feed conversion ratio & 15.22 & 9.51 & 9.62 & 11.60 & $4.11^{\mathrm{ns}}$ \\
\hline Average daily cost of diet (N.k) & $5.24^{\mathrm{b}}$ & $7.69^{\mathrm{a}}$ & $7.88^{\mathrm{a}}$ & $9.25^{\mathrm{a}}$ & 0.59 \\
\hline Cost to gain ratio (N.k/g) & 0.48 & 0.44 & 0.57 & 0.74 & $0.19^{\mathrm{ns}}$ \\
\hline Average litter size (No./litter) & $4.50^{\mathrm{bc}}$ & $6.00^{\mathrm{b}}$ & $8.00^{\mathrm{a}}$ & $3.00^{\mathrm{c}}$ & 0.60 \\
\hline Average birth weight of pups $(\mathrm{g})$ & $13100^{\mathrm{b}}$ & $140.10^{\mathrm{ab}}$ & $117.21^{\mathrm{b}}$ & $182.22^{\mathrm{a}}$ & 14.21 \\
\hline
\end{tabular}

${ }^{a b}$ Means along the same row having no common superscript differ significantly at $\mathrm{P}<0.01$; ns refers to non-significant differences between means 